\title{
Kajian Kualitas Airtanah Bebas antara Sungai Kuning dan Sungai Tepus di Kecamatan Ngemplak, Yogyakata, Indonesia
}

\author{
Aris Sutardi ${ }^{1}$, Slamet Suprayogi ${ }^{2}$ dan Tjahyo Nugroho Adji ${ }^{3}$ \\ SMA N I Mlati, Sleman Yogyakarta, Indonesia ${ }^{1}$, Fakultas Geografi, Universitas Gadjah Mada, Indonesia ${ }^{2,3}$ \\ Email koresponden:aris.sutardi@mail.ugm.ac.id
}

\begin{abstract}
Diterima: 08 November 2016/Disetujui: 31 januari 2017/ Publikasi online: 31 Maret 2017
( 2017 Fakultas Geografi UGM dan Ikatan Geograf Indonesia (IGI)

Abstrak Pertumbuhan penduduk di Kabupaten Sleman telah menempatkan banyak tekanan pada sumber daya air. Perkembangan ini berkembang pesat ke daerah pedesaan termasuk Ngaglik, Ngemplak dan Kalasan Kecamatan. Oleh karena itu, studi tentang kualitas air di daerah ini penting. Daerah antara Sungai Kuning dan Sungai Tepus merupakan daerah yang ideal untuk melakukan penelitian ini saerah ini meliputi 3 kecamatan yaitu: Ngaglik, Ngemplak dan Kalasan. Dalam penelitian ini, parameter untuk menilai kualitas air terbatas pada 4 parameter: Nitrat, Nitrit, Amoniak dan Fosfat. Penelitian ini dilakukan pada tahun 2015, pengambilan sampel purposive dipilih untuk mengumpulkan besar sampel air tanah. Penggunaan lahan dan kegiatan lain yang dianggap dapat menyebabkan polusi air seperti pertanian, catel, dan limbah domestik. Sampel dianalisis di laboratorium untuk menentukan konsentrasi Nitrat, Nitrit, amoniak dan fosfat. Secara total, 23 sampel dikumpulkan. Selama kerja lapangan, tabel air diukur untuk menghasilkan peta flownet. Peta flownet ini akan digunakan untuk menganalisis potensi pencemaran air tanah. Hasil penelitian ini menunjukkan bahwa Nitrat, Nitrit, amoniak, dan fosfat yang bervariasi. Kontaminasi Nitrat dan Nitrit dalam air tanah masih di bawah standar sebesar $10 \mathrm{mg} / \mathrm{L}$ untuk Nitrat dan 0,06 mg / L untuk Nitrit sementara amoniak dan fosfat berada di atas standar sebesar 0,02 $\mathrm{mg} / \mathrm{L}$ untuk amoniak dan $0,2 \mathrm{mg} / \mathrm{L}$ untuk fosfat. Tingginya jumlah amoniak ini disebabkan oleh kegiatan peternakan ayam sementara fosfat disebabkan oleh penggunaan pemupukan fosfat di daerah pertanian padi. Distribusi kualitas air tanah di daerah itu bervariasi berdasarkan penggunaan lahan, kegiatan orang dan aliran air tanah. Air tanah potensial pencemaran dilakukan berdasarkan aliran air tanah. Hasilnya menunjukkan bahwa daerah atas (utara) memiliki konsentrasi yang lebih rendah dari Nitrat, Nitrit, amoniak dan fosfat. Daerah pertengahan, di mana sebagian besar peternakan ayam dan pertanian berada, telah menjadi sumber pencemaran air.
\end{abstract}

Kata kunci: Air Tanah Kualitas, Nitrat; nitrit; amoniak; fosfat; distribusi

\begin{abstract}
Population growth in Sleman regency have put a lot of pressure on water resources. This development is growing rapidly into the rural area including Ngaglik, Ngemplak and Kalasan Sub-district. Therefore, study about water quality in these area is important. The area between Kuning River and Tepus River is an ideal area to conduct this research since its cover 3 sub-districts: Ngaglik, Ngemplak and Kalasan. In this research, the parameter to assess water quality is limited to 4 parameters: Nitrate, Nitrite, Ammoniac and Phosphate. The study was conducted in 2015. Purposive sampling was selected to collect the groundwater sampels. Landuse and other people activities that can contribute to water pollution such as farming, catel, and domestic waste were considered. The samples were analysed in laboratory to define the concentration of Nitrate, Nitrite, ammoniac and phosphate. In total, 23 samples were collected. During fieldwork, the water table were measured to generate the flownet map. This flownet map will be used to analyse the groundwater pollution potential. The result of this research shows that the Nitrate, Nitrite, ammoniac, and phosphate were varies. The contamination of Nitrate and Nitrite in the groundwater is still below standard by $10 \mathrm{mg} / \mathrm{L}$ for Nitrate and 0,06 $\mathrm{mg} / \mathrm{L}$ for Nitrite while ammoniac and phosphate were above standard by $0,02 \mathrm{mg} / \mathrm{L}$ for ammoniac and $0,2 \mathrm{mg} / \mathrm{L}$ for phosphate. These high number of ammoniac were caused by the chicken farming activities while phosphate were caused by the use of phosphate fertilization in the rice farming area. The distribution of groundwater quality in the area were varies based on the landuse, people activities and groundwater flow. The groundwater potential pollution were conducted based on the groundwater flow. The result show that the upper area (north) has lower concentration of Nitrate, Nitrite, ammoniac and phosphate. The mid area, where most of the chicken farm and rice farm are located, has become the sources of the water pollution.
\end{abstract}

Keywords: Groundwater Quality, Nitrate; Nitrite; ammoniac; phosphate; distribution

\section{PENDAHULUAN}

Kabupaten Sleman merupakan wilayah yang mulai berkembang pesat seiring dengan pertumbuhan jumlah penduduk. Pertumbuhan jumlah penduduk yang semakin besar dari waktu ke waktu memberikan dampak terhadap peningkatan aktivitas penduduk. Aktivitas penduduk yang meningkat berpengaruh pada peningkatan limbah baik limbah domestik, pertanian, perternakan, maupun industri. Namun, peningkatan aktivitas penduduk tersebut tidak diikuti dengan peningkatan sanitasi lingkungan yang baik sehingga dapat menyebabkan terjadinya pencemaran, termasuk pencemaran airtanah.

Survei lapangan tentang airtanah bebas di lokasi penelitian pada sumur gali dilakukan untuk memperoleh data tentang kedalaman muka airtanah, 
parameter airtanah terutama data kadar Nitrat, Nitrit, amonium, dan Phospat. Data kedalaman airtanah digunakan untuk membuat Flownet. Pengambilan sampel airtanah diperlukan untuk mengetahui kadar Nitrat, Nitrit, amonium, dan Phospat dengan cara menganalisisnya di laboratorium. Analisis yang dilakukan adalah analisis deskriptif kuantitatif untuk uji kualitas airtanah, analisis deskriptif spasial untuk persebaran pencemaran airtanah, dan deskriptif kualitatif untuk potensi pencemaran airtanah di lokasi penelitian.

Dalam rangka mengetahui kualitas dan potensi pencemaran airtanah yang terjadi akibat aktivitas penduduk di daerah penelitian sangat penting dilakukan penelitian. Penelitian kualitas airtanah yang dimaksud disini menggunakan parameter pencemar seperti Nitrat, Nitrit, Amonia, dan Phospat. Berdasarkan kajian kondisi kualitas airtanah dengan parameter tersebut maka dapat diketahui tingkat kualitas airtanah serta distribusi spasialnya, dengan demikian dapat memberikan informasi bagi masyarakat dan pemerintah dalam pengambilan kebijakan tentang pengelolaan airtanah di daerah penelitian.

\section{METODE PENELITIAN}

Metode penelitian yang digunakan dalam penelitian ini adalah survei lapangan dengan objeknya berupa airtanah pada sumur gali. Survei ini dilakukan untuk pengambilan data primer yaitu kedalaman muka airtanah dan sampel airtanah untuk uji Nitrat, Nitrit, Amonia, dan Phospat. Analisis yang dilakukan adalah analisis deskriptif kuantitatif untuk uji kualitas airtanah, analisis deskriptif spasial untuk persebaran pencemaran airtanah, dan deskriptif kualitatif untuk potensi pencemaran airtanah di lokasi penelitian.

Data primer yang dikumpulkan melalui pengukuran langsung di lapangan dan data sekunder yang bersumber dari Peraturan Gubernur DIY No. 20 Tahun 2008 tentang Baku Mutu Air dan berbagai literatur yang menunjang proses penelitian ini. Alat yang digunakan adalah Global Positioning System (GPS), pita meter, botol sebagai wadah sampel airtanah, EC meter, Checklist lapangan, Kamera dan seperangkat komputer dan software ArcGis 10.1. Bahanbahan yang digunakan meliputi sampel airtanah, bahan-bahan kimia yang diperlukan untuk uji laboratorium serta Peta Rupa Bumi Indonesia Lembar 1408-242, Pakem.

Pembuatan flownets menggunakan cara yang dikenal dengan Three Point Problem, yaitu dengan menggunakan interpolasi linier dari tiga titik yang berdekatan yang memiliki perbedaan tinggi muka airtanah (hydraulic head). Dengan membuat kontur airtanah yaitu menghubungkan titik-titik yang memiliki tinggi muka airtanah sama. Secara alami aliran airtanah akan memotong tegak lurus kontur airtanah pada kondisi akuifer yang homogen karena pengaruh potongan gravitasi yang lebih rendah. Arah aliran airtanah dapat digunakan untuk mengetahui arah pencemaran airtanah yang mungkin terjadi. Arah aliran airtanah mengikuti kemiringan topografinya dari muka airtanah (hydraulic head) tinggi menuju muka airtanah yang lebih rendah.

Kualitas airtanah yang dianalisis meliputi parameter fisik dan kimia. Parameter fisik meliputi pengukuran kedalaman airtanah, suhu dan Daya hantar listrik (DHL), sedangkan parameter kimia meliputi uji Nitrat, Nitrit, Amonia, dan Phospat. Parameter fisik dilakukan saat di lapangan sedangkan uji parameter kimia dilakukan di laboratorium.

Metode analisis yang digunakan dalam penelitian ini adalah deskriptif kuantitatif-kualitatif. Kegiatan analisis dilakukan dengan membandingkan nilai parameter kualitas airtanah yang diuji pada satu titik pengambilan sampel dengan sampel lainnya. Nilai kualitas airtanah yang diperoleh ini kemudian disajikan dalam bentuk tabel dan diagram.

Selanjutnya nilai setiap parameter dalam uji kualitas air juga disajikan dalam bentuk peta untuk mengetahui persebaran secara spasial pada masingmasing parameter. Distribusi nilai parameter yang digambarkan pada peta ini dapat digunakan pula untuk mengetahui potensi pencemaran yang ada di wilayah penelitian.

\section{HASIL DAN PEMBAHASAN}

Berdasarkan pada pelaksanaan dengan metode penelitian yang telah dikemukakan di atas maka berikut ini dipaparkan hasil-hasil penelitian dan kajiannya.

Dari analisis laboratorium yang kemudian dikonfirmasikan dengan Peraturan Gubernur DIY No. 20 Tahun 2008 tentang Baku Mutu Air menunjukkan bahwa terdapat suatu pola yang berbeda di daerah hulu dan hilir. Hal ini dapat disimpulkan bahwa didaerah hilir nilai kadar Amonianya lebih besar dibandingkan daerah hulu. Keadaan ini didukung dengan arah aliran airtanah yang mengalir dari hulu (utara) ke hilir (selatan). Arah aliran airtanah ini dapat dilihat pada peta flownet yang telah dibuat. Amonia (NH3) dan garam-garamnya bersifat mudah larut dalam air. Sumber Amonia adalah reduksi gas Nitrogen yang berasal dari proses difusi udara atmosfer, limbah industri dan domestik.

Nilai kadar Amonia di daerah hulu tergolong kecil dengan nilai bervariasi antara 0,01 - 0,02 mg/l, masih tergolong kecil, di bawah baku mutu air menurut Peraturan Gubernur DIY No. 20 tahun 2008 yang menetapkan untuk air kulitas I sebesar $0,02 \mathrm{mg} / \mathrm{l}$. Nilai kadar Amonia di daerah tengah meningkat, ditemukan kadar Amonia di daerah tengah berkisar antara 0,03 0,04 mg/l. Nilai kadar Amonia di daerah tengah dan hilir telah melebihi baku mutu air yang ditetapkan Peraturan Gubernur DIY No. 20 tahun 2008, yaitu semakin ke arah hilir daerah kajian menunjukkan nilai yang semakin tinggi, kadar Amonia yang ditemukan hingga mencapai 0,05-0,06 mg/l.

Dari tinjauan pola penggunaan lahan menunjukkan 
bahwa sumur yang diambil airnya untuk diteliti memiliki jarak yang cukup dekat dengan pemukiman dan juga daerah persawahan. Menurut Glanville (1993) jarak antara sumur sebagai penyedia air bersih dan Sawah yang direkomendasikan minimum sekitar 50 meter. Hal inilah yang menyebabkan ditemukannya Kadar Nitrat yang melebihi baku mutu di daerah ini (gambar 1).

Hasil nilai kadar Nitrat pada bagian hulu daerah penelitian telah melebihi batas standar maksimal yang dibolehkan, (berdasarkan Peraturan Gubernur DIY No. 20 tahun 2008 untuk kualitas Kelas I sebesar 10 mg/l). Nilai kadar Nitrat tertinggi diperoleh dari pengambilan sampel pada titik A1 sebesar 18,789 mg/l. Nilai kadar Nitrat yang berada pada kisaran di atas $10 \mathrm{mg} / \mathrm{l}$ juga dijumpai pada titik A3 sebesar 13,813 mg/l, titik A6 sebesar 11,202 mg/l dan titik B4 sebesar 18,218 mg/l.

Semakin ke arah selatan kadar Nitrat kembali berkurang hal ini disebabkan oleh kemampuan self purification oleh tanah sehingga semakin aritanah mengalir ke selatan.Kadar Nitrat menjadi berkurang.

\section{Analisis Kadar Nitrit}

Pola distribusi persebaran kadar Nitrit hampir sama dengan pola distribusi persebaran kadar Amonia. Pola pada peta iso Nitrit menunjukkan nilai yang berbeda pada daerah hulu, tengah dan hilir daerah penelitian. Persebaran kadar nitirit hampir sama dengan persebaran kadar Amonia. Kadar Nitrit pada daerah hilir (bagian utara) cenderung kecil dengan angka berkisar 0,0009-0,004 mg/l. Kemudian semakin ke arah hilir (selatan) kadar Nitrit semakin tinggi dengan nilai kadar berkisar antara 0,004-0,007 mg/l.

Perbedaan nilai kadar Nitrit di daeah kajian dipengaruhi oleh faktor utama penggunaan lahan didaerah ini. Penggunaan lahan di daerah utara dan selatan cenderung memiliki perbedaan. Dibagian utara jarang ditemui pemukiman dan juga peternakan sedangkan dibagian tengah hingga selatan banyak ditemui penggunaan lahan tersebut. Nitrit merupakan zat yang banyak dipengaruhi oleh aktivitas peternakan dan limbah rumah tangga. Selain itu terdapatnya penggunaan pupuk kimia juga dapat mempengaruhi

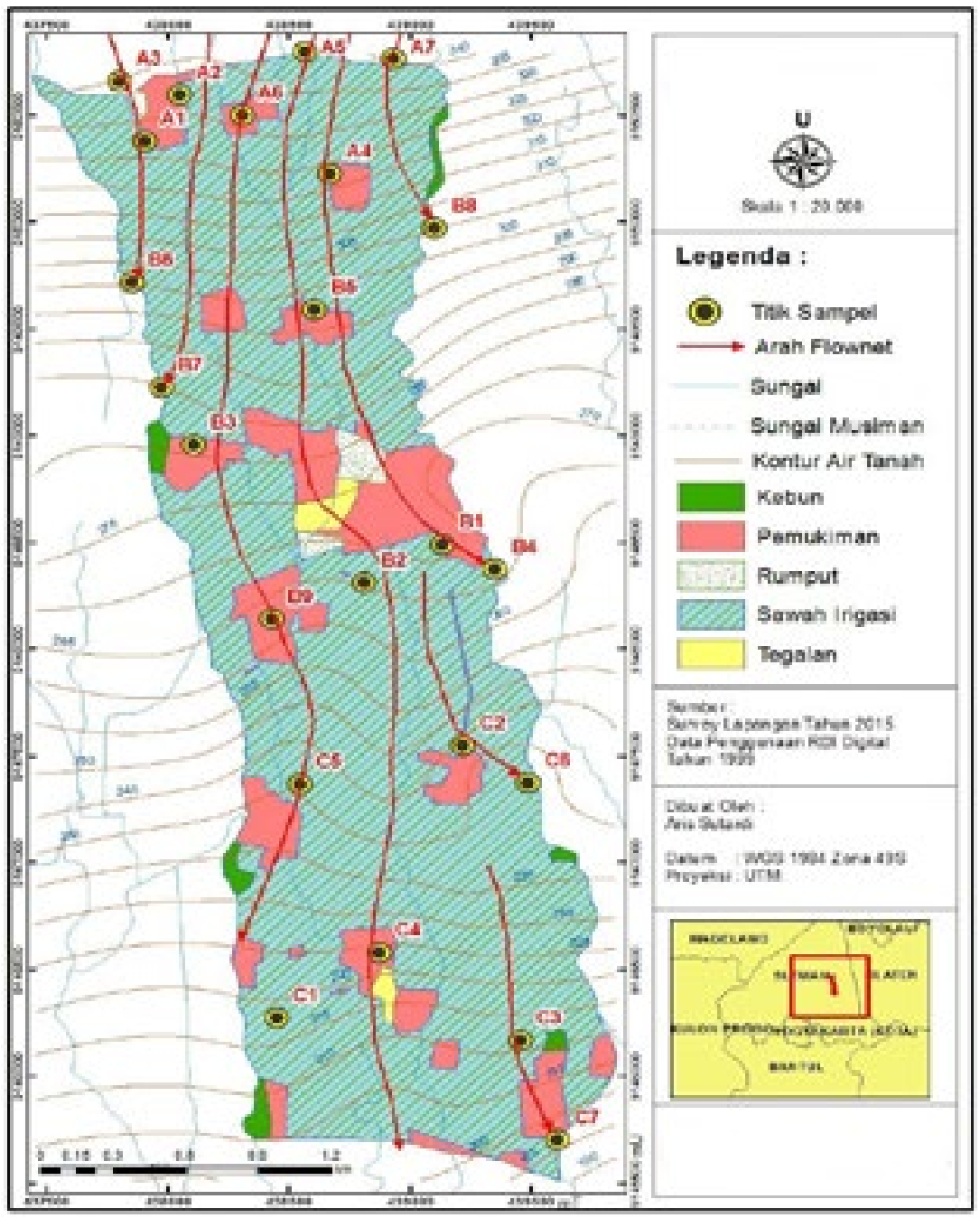

Gambar 1. Peta Flownet Daerah Penelitan Sumber: Survai lapangan tahun 2015. 
kadar Nitrit di suatu wilayah.

\section{Analisis Kadar Phosphat}

Mengenai pengujian kadar Phospat pada 23 sampel airtanah yang ada, secara umum semua sampel berada diatas baku mutu sebesar $0.2 \mathrm{mg} / \mathrm{l}$. Kondisi ini dapat diakibatkan wilayah kajian yang didominasi oleh persawahan dan permukiman. Phospat sendiri dapat bersumber dari aktivitas manusia baik dari limbah domestik maupun pertanian. Pupuk pada sektor pertanian banyak mengandung fosfor, sehingga sampel air pada wilayah kajian mengandung Phospat tinggi

Distribusi kadar Phospat memiliki pola yang berbeda dengan distribusi Kadar zat lain didaerah kajian. Distribusi Phospat didaerah ini tersebar cukup merata dengan nilai terkecil $0,02 \mathrm{mg} / \mathrm{l}$. hingga nilai terbesar 1,09 mg/l. persebaran Kadar Phospat pada airtanah di daerah penelitian menunjukkan pola semakin ke arah hilir Kadar Phospat semakin tinggi. Di daerah hilir atau bagian selatan daerah penelitian sekitar Desa Selomartani kadar Phospat bisa mencapai 2,2 mg/l. Kadar Phospat ini sangat tinggi dan telah melebihi ambang batas baku mutu air menurut Peraturan Gubernur DIY No. 20 tahun 2008 untuk Kelas I sebesar 0,2 mg/l.

Kadar Phospat ini dipengaruhi oleh faktor banyaknya pertanian intensif di daerah kajian. Pertanian intensif ini akan menggunakan pupuk kimia dengan jumlah banyak untuk menyuburkan tanah, hal inilah yang kemudian dapat mempengaruhi kadar Phospat di dalam airtanah dangkal. Pupuk kimia mengandung banyak Phospat. Sumber lain dari Phospat yaitu deterjen dan sabun. Pemanfaatan deterjen dan sabun dengan intensitas yang tinggi berasal dari permukiman yang menghasilkan limbah domestik.

\section{Uji Regresi Parameter Kualitas Air}

Hasil uji kimia di laboratorium pada sampel airtanah dilakukan uji statistika regresi untuk mengetahui besarnya pengaruh limbah yang dibuang langsung ke alam terhadap kualitas sampel airtanah. Analisis statistik regresi yang dilakukan adalah dengan menghubungkan antara nilai dari kadar senyawa pencemar (Nitrit, Nitrat, Amonia, dan Phospat) dengan pH-nya.

Uji regresi tentang hubungan peningkatan $\mathrm{pH}$ dengan kadar Nitrat (dalam mg/l.) ditemukan bahwa meningkatnya kadar Nitrat, nilai pH-nya semakin berkurang, dari kondisi ini menunjukkan antara kadar Nitrat di daerah penelitian terhadap $\mathrm{pH}$ tidak memiliki pengaruh yang kuat, hal ini berbeda dengan zat lain (Nitrit, Amonia dan Phospat) yang menunjukkan peningkatan kadar memberikan dampak peningkatan pH air. Uji regresi kadar Amonia, Nitrat, Nitrit dan Phospat terhadap pH ditunjukkan oleh Gambar 2.

Grafik Regresi Hubungan Kadar Amonia dengan pH pada Sampel Airtanah Grafik Regresi Hubungan Kadar Nitrat dengan $\mathrm{pH}$ pada Sampel Airtanah

Grafik Regresi Hubungan Kadar Nitrit dengan $\mathrm{pH}$ pada Sampel Airtanah Grafik Regresi Hubungan Kadar Phospat dengan $\mathrm{pH}$ pada Sampel Airtanah

\section{Analisis Potensi dan Dampak Pencemaran Kualitas Airtanah}

Potensi pencemar pada daerah penelitian berdasarkan uraian pada bab sebelumnya merupakan hasil dari dominan berasal kegiatan masyarakat. Hasil analisis menunjukkan pencemaran paling besar

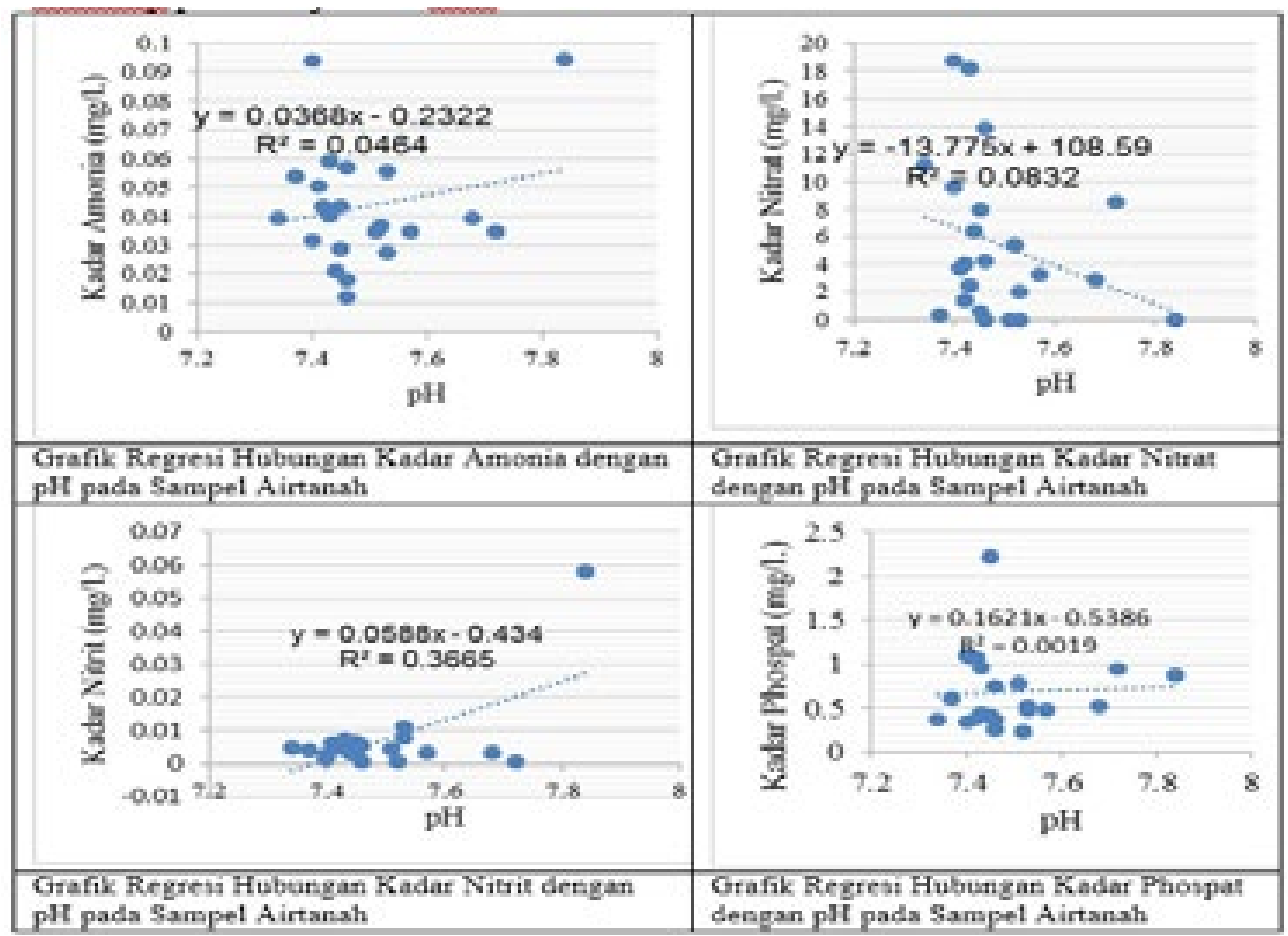

Gambar 2. Uji regresi hubungan Kadar Amonia, Nitrat, Nitrit dan Phospat dengan pH 
adalah Kadar Amonia diikuti dengan Phospat. Amonia memilki nilai cukup tinggi dan sebagian besar sampel airtanah yang diambil memilki kadar kimia Amonia melebihi kadar baku mutu yang diperbolehkan. Phospat menempati potensi pencemar kedua yang juga sebagian besar sampel melebihi baku mutu airtanah. Kadar Nitrat meskipun pada beberapa sampel melebihi kapasitas baku mutu namun sebagian besar masih di bawah. Begitu pun dengan Nitrit yang masih dalam kadar aman pada daerah penelitian. Perbandingan kadar kimia airtanah Amonia, Phospat, Nitrat dan Nitrit dengan baku mutu air yang mengacu pada Peraturan Gubernur DIY No. 20 Tahun 2008 tentang Baku Mutu Air (maksimal kadar Amonia sebesar 0,02 mg/l., Nitrat sebesar 10 mg/l., Nitrit sebesar 0,06 mg/l., dan Phospat sebesar 0,02 mg/l. ditunjukkan pada Gambar 3.

Potensi Pencemaran airtanah dengan kadar Amonia umumnya berasal dari kegiatan peternakan. Daerah penelitian tersebar banyak peternakan dengan skala rendah hingga tingi.

Sebaran kadar Amonia tinggi berada pada daerah tengah dan menuju bagian hilir daerah penelitian. Daerah sumber pencemar dari limbah peternakan tersebar pada bagian tengah daerah penelitian. Dampak posisi sumber pencemar di tengah adalah aliran pencemar yang menuju ke daerah hilir. Hal tersebut dapat terjadi akibat aliran airtanah dari flownet memiliki arah menuju ke daerah hilir dari sumber pencemar Amonia yaitu limbah peternakan. Sebaran potensi pencemar Amonia ditunjukkan Gambar 4.

Konsentrasi kadar Amonia rendah berada pada bagian hulu daerah penelitian. Bagian hulu dominan merupakan daerah sawah, kebun dan sebagian permukiman. Kegiatan peternakan sebagai sumber pencemar tidak ditemukan pada bagian hulu.

Kadar pencemar tertinggi kedua adalah Phospat. Phospat berasal dari kegiatan pertanian dan limbah domestik rumah tangga. Kegiatan pertanian cukup banyak dilakukan mulai dari persawahan, perkebunan, sedangkan limbah domestik dengan aktivitas rumah tangga di dalamnya menyumbang limbah sabun dan sisa rumah tangga yang meresap ke dalam tanah hingga mencemari airtanah. Distribusi potensi pencemar Phospat dapat dilihat pada Gambar 5.

Distribusi kadar Nitrat dan Nitrit memiliki perbedaan. Nitrat dengan sumber pencamar pupuk urea dan limbah perikanan, justru kadar tinggi berada di bagian atas. Bagian atas teridentifikasi terdapat banyak kegiatan pertanian serta kolam ikan. Meskipun di daerah bawah juga terdapat beberapa kegiatan perikanan dan pertanian namun konsentrasi Nitrat lenbih rendah. Hal tersebut pencemaran pada airtanah langsung mengalir menuju daerah yang lebih hilir. Pencemaran Nitrit justru memilki kadar tinggi pada bagian bawah. Hal tersebut sumber pencemar pada Nitrat berada pada bagian tengah dengan indiksi dari kegiatan peternakan dan pertanian. (Gambar.6 dan Gambar.7).

Secara umum dampak dari pencemaran airtanah di daerah penelitian paling besar berada pada daerah hilir, Kondisi tersebut didukung oleh aliran airtanah dari daerah hulu menuju ke daerah hilir sehingga aktvitas pencemar yang telah mencemari airtanah setempat akan mengalir menuju ke daerah yang lebih rendah atau daerah hilir.

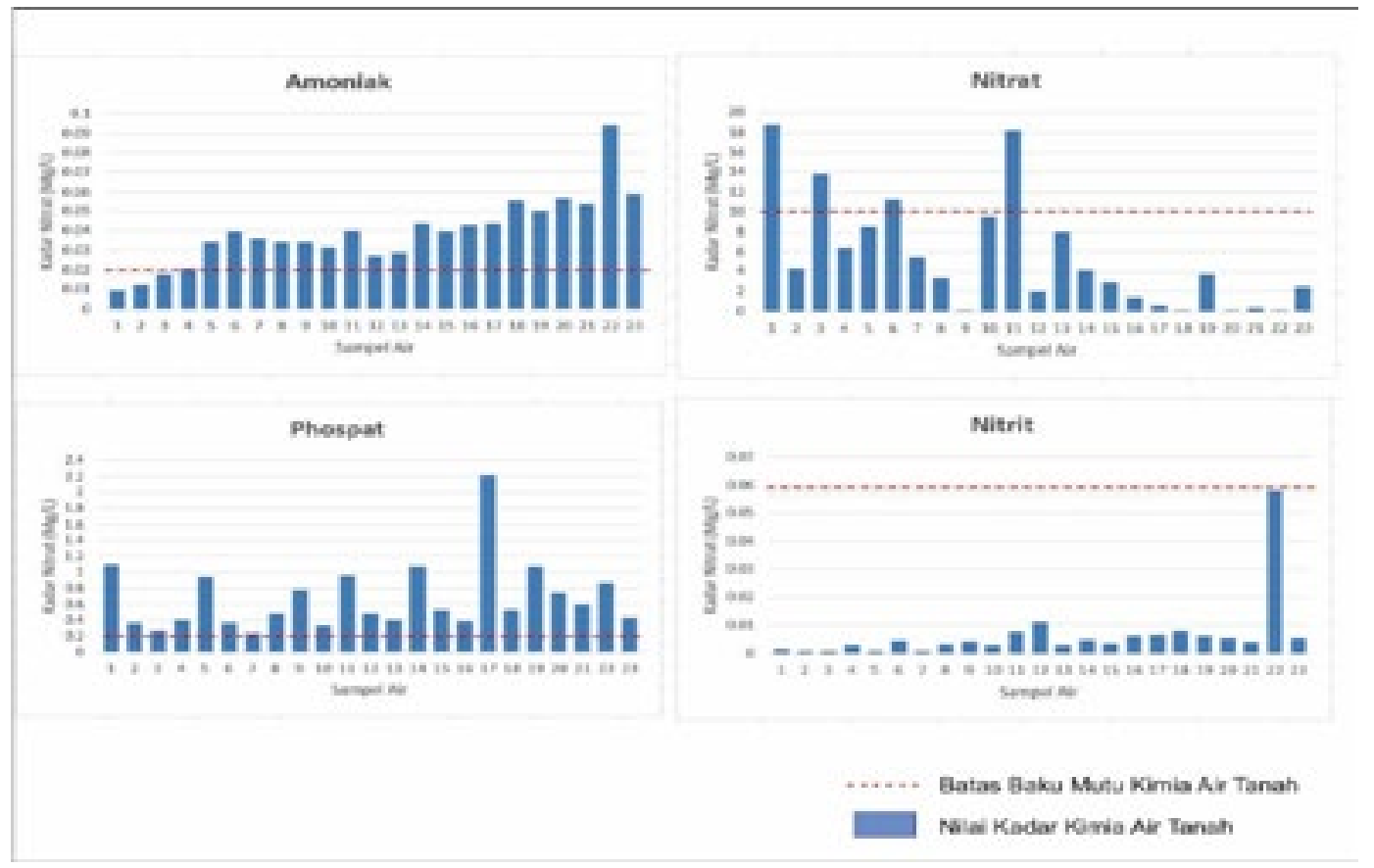

Gambar 3.Grafik Perbandingan Nilai Kadar Kimia Airtanah dengan Baku Mutu Air 


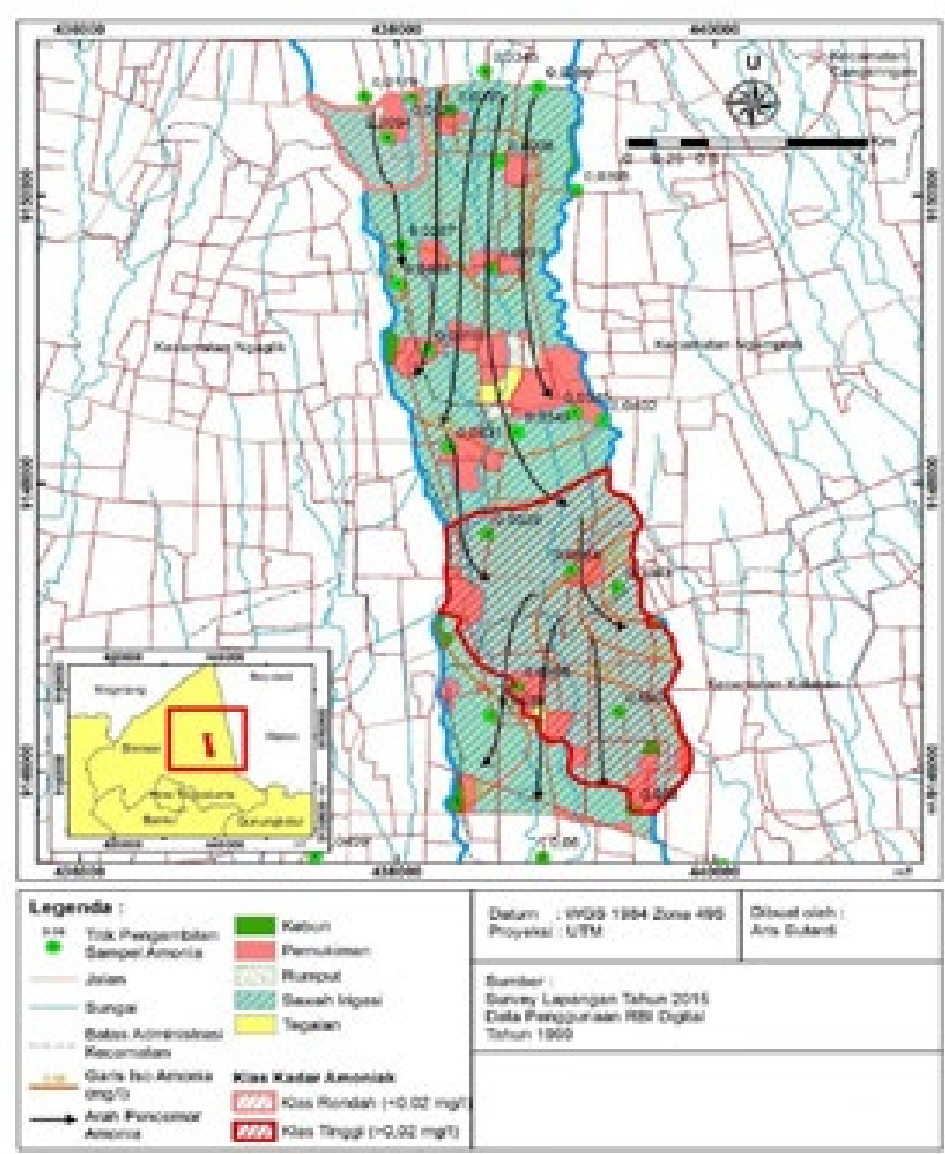

Gambar 4. Peta Potensi Pencemar Amonia Daerah Penelitian

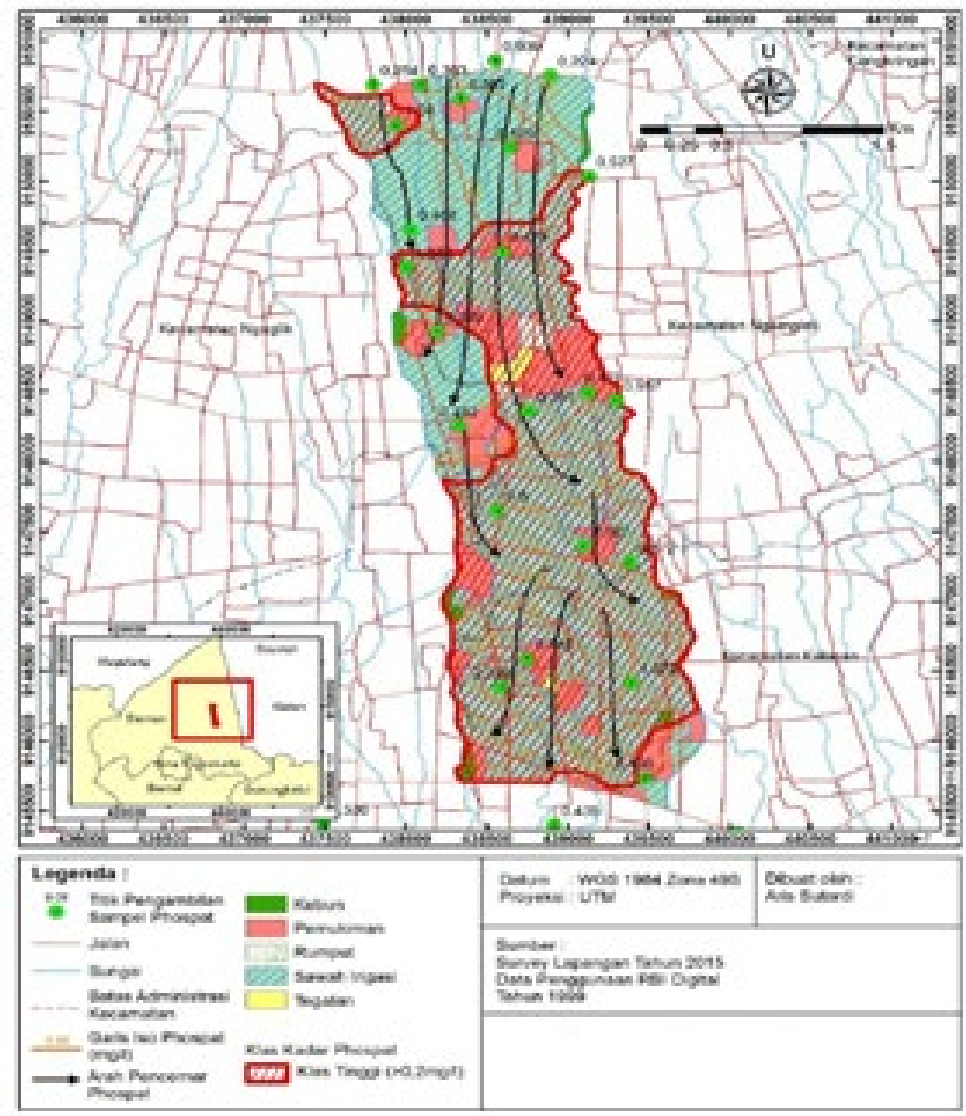

Gambar 5. Peta Potensi Pencemar Phospat Daerah Penelitian 


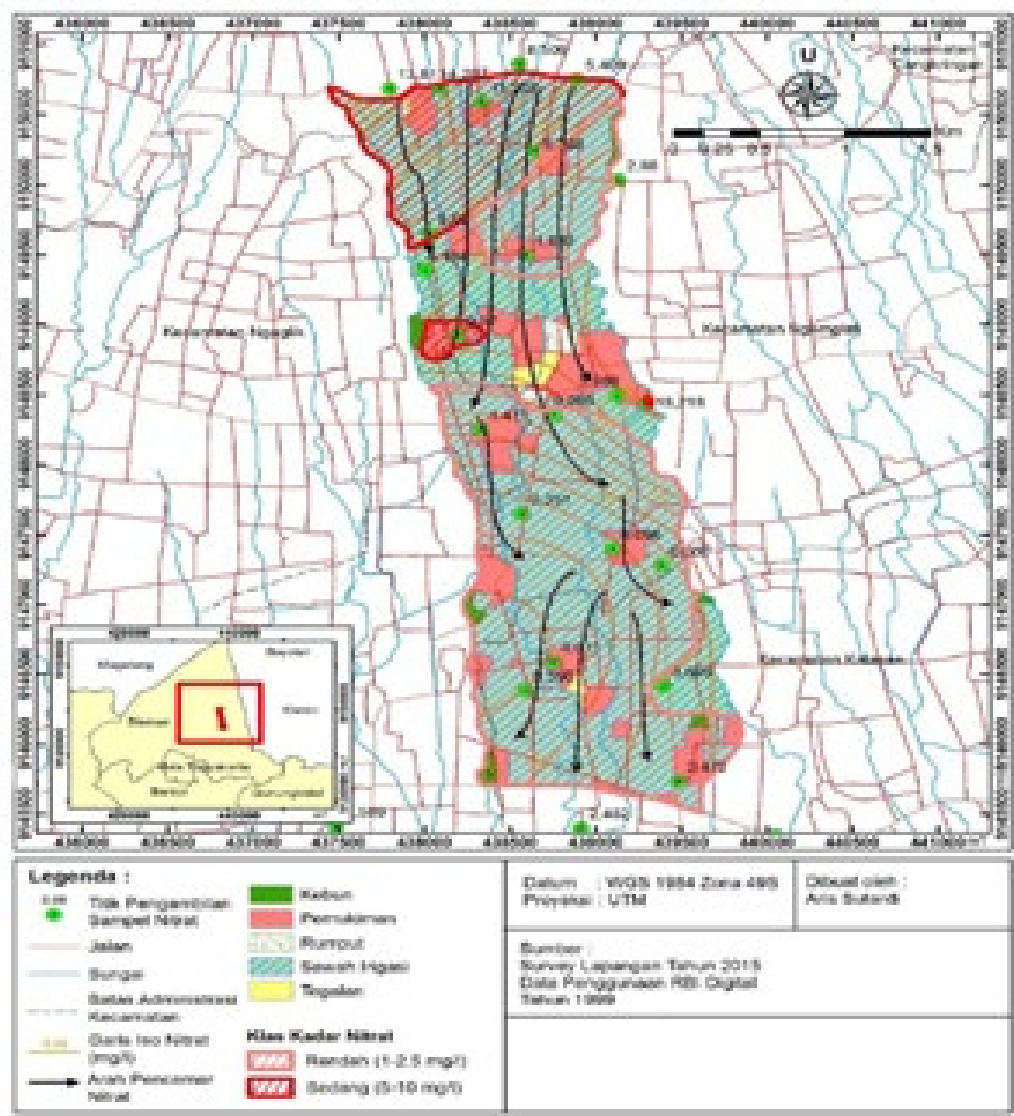

Gambar 6. Peta Potensi Pencemar Kadar Nitrat Daerah Penelitian

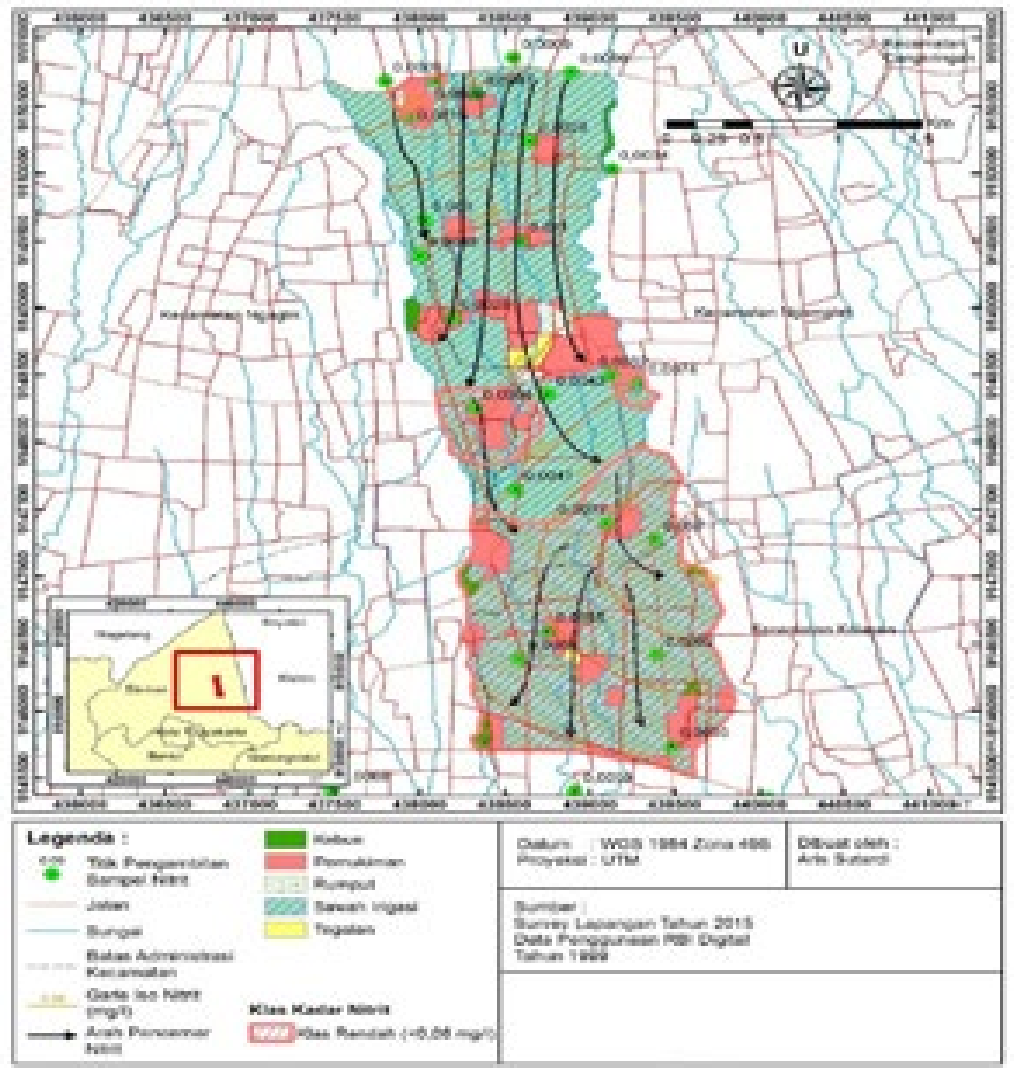

Gambar 7. Peta Potensi Pencemar Nitrit Daerah Penelitian 


\section{KESIMPULAN}

Berdasarkan penelitian yang telah dilaksanakan dapat diambil kesimpulan

Berdasarkan parameter Nitrat, Nitrit, Amonia dan Phospat diperoleh nilai yang bervariasi, Kadar Nitrat dan Nitrit relatif dibawah baku mutu air. Variasi kualitas air yg lebih besar terdapat pada kadar Amonia dan Phospat, kadar Amonia yang tinggi diakibatkan oleh bahan organik hasil kegiatan peternakan dan kadar Phospat yang tinggi diakibatkan oleh penggunaan pupuk Phospat pada kegiatan pertanian. Distribusi tingkat kadar Nitrat, Nitrit, Amonia dan Phospat dalam airtanah pada daerah penelitian dipengaruhi oleh pola penggunaan lahan dan karakteristik aliran airtanah yang ada. Perbedaan penggunaan lahan mengakibatkan perbedaan kadar Nitrat, Nitrit, Amonia dan Phospat. Perbedaaan karakteristik kadar bahanbahan di daerah penelitian tersebut terbagi menjadi tiga bagian yaitu bagian hulu, bagian tengah dan bagian hilir. Potensi pencemaran pada daerah penelitian dengan membandingkan arah aliran airtanah melalui flownet yang mengalir dari daerah hulu (bagian Utara) menuju daerah penelitian paling hilir (bagian paling selatan) menunjukkan bagian hulu memiliki akumulasi bahan pencemar paling rendah, sedangkan menuju ke hilir (selatan) makin tinggi. Daerah tengah dengan banyaknya aktifitas penggunaan lahan untuk usaha peternakan dan perikanan menjadikan daerah tengah sebagai sumber potensi pencemar yang akan menuju ke hilir (bagian selatan). Dampak yang ditimbulkan selain bahan pencemar terakumulasi daerah hilir apabila tidak diatasi dapat berakibat bagi merugikan bagi kesehatan jika airtanah tersebut digunakan untuk keperluan rumah tangga terutama jika digunakan sebagai air minum.

\section{DAFTAR PUSTAKA}

Adhikary, PP., Chandrasekharan, H., Dash J.Ch., Rajput T.B.S., Dubey S.K., (2011). Evaluation of Groundwater Quality for Irrigation and Drinking using GIS and Geostatistics in a Peri-urban area of Delhi, India, (internet), April Vol. 5, hal. 14231434. <http://www.springerlink.com.> (diakses 19 Juni 2013).

Badan Pusat Statistik (BPS), (2010). Kabupaten Sleman Dalam Angka Tahun 2010.

Badan Pusat Statistik (BPS), (2011). Kabupaten Sleman Dalam Angka Tahun 2011.

Badan Pusat Statistik (BPS), (2012). Kabupaten Sleman Dalam Angka Tahun 2012.

Badan Pusat Statistik (BPS), (2013). Kabupaten Sleman Dalam Angka Tahun 2013.

Badan Pusat Statistik (BPS), (2014). Kabupaten Sleman Dalam Angka Tahun 2014.

Basuki, Nur., (2011). Pemodelan Spasial Penyebaran Nitrat Pada Air Sumur Gali : Studi Kasus Di Kelurahan Purbayan Kecamatan Kotagede Yogyakarta. Thesis: Universitas Gadjah Mada.
Bayong, Tj.H.K., (2000). Klimatologi, Bandung: ITB.

Budi, (2011). Mofologi-Merapi Vulcano.jpg (internet), <http://bangbudi.blog.ugm.ac.id/ files/2011/07/> (diakses 17 Desember 2014.

Fetter, C.W., (1988). Applied Hydrology, Ohio: Merrill Pubs. Co. Columbus Ohio United States of America.

Effendi, H., (2003). Telaah Kualitas Air, Yogyakarta: Kanisius.

Ekadinata, A., Dewi, S., Hadi, D., Nugroho, D., dan Johana, F., (2008). Sistem Informasi Geografis Untuk Pengelolaan Bentang lahan Berbasis Sumber Daya Alam. Buku 1: Sistem Informasi Geografis dan Penginderaan Jauh Menggunakan ILWIS Open Source, Bogor: World Agroforestry Centre.

Glanville, T., (1993). Good Wells For Save Water, Iowa: IOWA States University.

Linsey Ray, K., and Franzini Joseph, B., (1989). Teknik Sumber Daya Air, Edisi ke Tiga, Jakarta: Erlangga.

Lindsay, D.R., Martin, G.B., Williams, I.H., (1993). Nutrition and Reproduction, In World Animal Science B.9 Reproduction in Domesticated Animal. Ed. King, G.J.. Amsterdam: Elsevier.

Odum, E.P., (1996). Dasar-Dasar Ekologi, Alih Bahasa. Cahyono, S. FMIPA IPB. Yogyakarta: Gadjah Mada University Press.

Pemerintah Daerah Istimewa Yogyakarta, (2008). Peraturan Gubernur Daerah Istimewa Yogyakarta Nomor 20 Tahun 2008 tentang Baku Mutu Air di Provinsi Daerah Istimewa Yogyakarta, Yogyakarta: Sekretaris Daerah.

Republik Indonesia, (2001). Peraturan Pemerintah Republik Indonesia No. 82 Tahun 2001 Tentang Pengelolaan Kualitas Air dan Pengendalian Pencemaran Air. Jakarta: Sekretaris Negara.

Purnama, S., (2010). Hidrologi Airtanah, Yogyakarta: Kanisius.

Sartohadi, J., Jamulya, Dewi, N.I.S., (2012). Geografi Tanah, Yogyakarta: Pustaka Pelajar.

Seyhan, Ersin, (1990). Dasar-dasar Hidrologi, Yogyakarta: Gajah Mada University Press

Sudarmadji, (1991). Agihan Geografi dan Kimiawi Airtanah Bebas Kotamadya Yogyakarta, Disertasi, Yogyakarta: Pasca Sarjana Universitas Gadjah Mada.

Suharjo, B., (2013). Statistika Terapan, Yogyakarta: Graha Ilmu.

Todd, D.K., (1980). Groundwater Hydrology, New York: John Wiley and Sons, Ltd. 